\title{
Comparative effects of different fertilizer types on proximate composition and pigments concentration of Pumpkin (Cucurbita maxima L.) in Southwestern Nigeria
}

\author{
Adeona Adedamola Peace ${ }^{1 *}$ and Akande Gladys Monisola ${ }^{2}$ \\ ${ }^{1}$ Department of Crop, Soil and Pest Management, Federal University of Technology, P.M.B 704, Akure, Ondo State, \\ Nigeria \\ ${ }^{2}$ Department of Soil and Environmental Management, Kogi State University, P.M.B 1008, Anyigba Kogi State, Nigeria \\ *Corresponding Author: dharmmie0805@gmail.com
}

\begin{abstract}
An investigation of Comparative effects of different fertilizer types on proximate composition and pigments concentration of Pumpkin (Cucurbita maxima) was conducted at the teaching and research farm of Federal University of Technology, Akure Nigeria between April and June, 2018 and May and June, 2019. The following fertilizer types were used as treatments, N:P:K = 20:10:10 at $250 \mathrm{~kg} \mathrm{ha}^{-1}$, Sunshine organomineral fertilizer at $5 \mathrm{t} \mathrm{ha}^{-1}$ and fertiPlus at $6 \mathrm{t} \mathrm{ha}^{-1}$. Experiment was laid out in a Randomized Complete Block Design involving three replications per treatment. Standard analytical methods were used to determine moisture content, ash, protein, calcium, ascorbic, carbohydrate, fat, fiber, chlorophyll and carotenoid at harvesting stage. Data collected were subjected to analysis of variance (ANOVA) and means were compared using Duncan's Multiple Range Test $(\mathrm{DMRT})$ at $\mathrm{p}<0.05$. Results indicated that, fertilizer types significantly influence proximate and pigments concentration of pumpkin. The highest concentrations of proximate and pigments concentration were found from the leaf of pumpkin treated with NPK and fertiplus fertilizer. NPK fertilizer gave highest values of ash $(2.75 \%)$, calcium $(1.20 \mathrm{mg} / 100 \mathrm{~g})$, carbohydrate $(64.21 \%)$ and carotenoid (10.55) in the first cropping season (2018) while at the second cropping season (2019), NPK gave the highest value of ash $(2.72 \%)$, protein $(1.20 \%)$, calcium $(61.66 \mathrm{mg} / 100 \mathrm{~g})$ and carotenoid concentration (10.01) while the fertiplus fertilizer gave the highest value of fibre $(2.80 \%)$, chlorophyll (0.75) and ascorbic acid (266.67 mg / $100 \mathrm{~g}$ ) in the first and second cropping season (2018 and 2019) with highest fat concentration (2.92\%) record at the second cropping season. Except for the control plant that gave the highest values of protein and fat contents at the first cropping season (2018) and highest moisture contents and carbohydrate concentration at the second cropping season (2019). From this study, it shows that fertilizer types significantly influence the quality and bioactive compounds of pumpkin but influenced proximate and pigments composition differently.
\end{abstract}

Keywords: Fertilizer types, Pumpkin, Proximate analysis, Pigments concentration.

\section{INTRODUCTION}

Pumpkin is one of the most important vegetable indigenous to Southern Nigeria and grown in the forest zone of west African. Pumpkin is a cultivated plant of the genus Cucurbita whose young leaf is used as a cooked vegetable in South-western Nigeria. It has been reported that, the leaf is highly nutritional, medicinal and rich in protein about (29\%), fat (18\%), minerals and vitamins (20\%) (Akanbi \& Olaniyi, 2007). Among the positive health benefits attributed to this vegetable is its high antioxidant concentrates (Nicoli et al., 1999). These antioxidants are micronutrients that possess the ability to neutralize free radicals that may be causative agents to several major human ailments including cancer, cardiovascular diseases, neural disorders, diabetes, arthritis and prevent artheriosclerosis, high blood pressure, heart diseases and it can also be used as blood purifiers (Aletor et al., 2002; Jariene et al., 2007).

There is a growing interest to know the proximate and pigments concentration of pumpkin as influence by fertilizer types. Fertilizer has been defined as any organic or inorganic material of natural or synthetic origin that supplies one or more nutrients to plant when applied to soil. The literature had suggested that, the fertilizer types can affect the production and nutritional value of plants (Oloyede et al., 2012, Sabrina et al., 2012, Omar et al., 2012). Despite the benefit of pumpkin in Nigeria a lot of challenges is faced by farmers in it productions due to loss of soil fertility in most Nigeria soil as a result of land degradation. There is a need for soil amendments by the use of fertilizer as a source of nutrients and to increase quantity and quality of pumpkin.

Use of chemical fertilizer has been a supplement in nutrient sources to improve both quantity and quality and the nutritional value when apply to the soil (Akanbi et al., 2005; Aderi et al., 2011; Nwite et al., 2012). In addition, several researchers have proved that, fertilizer types improved soil properties, proximate and pigments concentration in crop (Akanbi et al., 2010; Olaniyi et al., 2010). 
Due to this challenges faced by farmers in the productions of pumpkin in Nigeria and also due to scare studies on the proximate composition of pumpkin treated with different fertilizer types in Southwest Nigeria. There is a need to determine the Comparative effects of inorganic fertilizer such as NPK, Organomineral and Fertiplus fertilizer on proximate composition and pigment concentration of a fast growing vegetable like pumpkin as to justify the continuous use of this fertilizer types in pumpkin production because application of fertilizers to soil did not only improve yield but also has significant effect on the quality and nutritional contents of food crops. Hence, this research aims to assess the Comparative effects of different fertilizer types on proximate composition and pigments concentration of Pumpkin (Cucurbita maxima L.) in Southwestern Nigeria.

\section{MATERIALS AND METHODS}

\section{Study site description}

The study was conducted during 2018 and 2019 cropping season at the Teaching and Research Farm of the Federal University of Technology, Akure, Ondo State Nigeria, between April and July. Akure lies within the tropical rainforest belt, latitude $5^{\circ} \mathrm{N}$ and longitude $15^{\circ} \mathrm{E}$. The rainfall pattern of Akure is bimodal with a wet season of about eight months occurring from April to October and with a brief dry spell, which in most cases occurs in the second half of the year. The peak rainfall periods are between July and October while the short dry season is from November through March with a mean annual precipitation of 1000 to $1250 \mathrm{~mm}$ and a mean daily temperature ranges from about $27^{\circ} \mathrm{C}$ and $37^{\circ} \mathrm{C}$, with an elevation ranged from 255 to 381 meters above sea level.

\section{Sources of materials}

The planting material (seeds) of Cucurbita maxima (Pumpkin) was obtained from the Nigeria Cereal Research Institute Oyo State, Nigeria.

\section{Cultural practices}

The site was manually cleared and debris was packed along the borders to ensure a clean weed-free seed bed for sowing crops. Beds were raised to about $60 \mathrm{~cm}$ manually leveled above ground level. Two seeds were sown per hole at a spacing of $1 \mathrm{~m} \times 1 \mathrm{~m}$ for pumpkin and later thinned down to one seedling per stand at two weeks after planting. The application of fertilizer treatments was done two weeks after planting by ring placement. The following fertilizer types were used as treatments, $\mathrm{N}: \mathrm{P}: \mathrm{K}=20: 10: 10$ at $250 \mathrm{~kg} \mathrm{ha}^{-1}$, Sunshine organomineral fertilizer at $5 \mathrm{t} \mathrm{ha}^{-1}$ and fertiPlus (organic fertilizer) at $6 \mathrm{t} \mathrm{ha}^{-1}$. The experiment was laid out in a randomized complete block design involving three replications per treatment.

\section{Laboratory analyses}

Young leaf of pumpkin was harvested at 6 weeks after planting. Proximate analysis of field pumpkin was carried out to determine the moisture, fat, ash, crude fiber, and protein and carbohydrate contents according to AOAC method (1990). While the pigments concentration such as chlorophyll and carotenoids were extracted with ice-cold acetone until the samples became colorless. The crude extract $(50 \mathrm{ml})$ was taken in a separating funnel; $100 \mathrm{ml}$ of petroleum ether and $100 \mathrm{ml}$ of aqueous sodium chloride $(25 \%, \mathrm{w} / \mathrm{v})$ were added, after mixing well, the upper layer was separated. The absorbance of the solution was read $663 \mathrm{~nm}, 645 \mathrm{~nm}$ and $450 \mathrm{~nm}$ against the solvent blank respectively.

\section{Statistical analysis}

Data collected were subjected to analysis of variance (ANOVA) using SPSS Version 15. Significant means were compared using Duncan's Multiple Range Test (DMRT).

\section{RESULTS}

The results of the Comparative effects of different fertilizer types on proximate composition and pigments concentration of Pumpkin (Cucurbita maxima) at harvesting during the first and second cropping season was shown in table 1 and 2. Fertilizer types significantly influence the ash, calcium, carotenoid, and carbohydrate concentration at the first cropping season (2018) and fibre, chlorophyll, ascorbic acid concentration at both season (2018 and 2019).

NPK fertilizer gave highest values of ash (2.75\%), calcium (1.20 mg / $100 \mathrm{~g})$, carbohydrate $(64.21 \%)$ and carotenoid (10.55) in the first cropping season (2018) while at the second cropping season (2019), NPK gave the highest value of ash $(2.72 \%)$, protein $(1.20 \%)$, calcium $(61.66 \mathrm{mg} / 100 \mathrm{~g})$ and carotenoid concentration (10.01) compared to other treatments while the fertiplus fertilizer gave the highest value of fibre (2.80\%), chlorophyll (0.75) and ascorbic acid $(266.67 \mathrm{mg} / 100 \mathrm{~g})$ in the first and second cropping season (2018 and 2019) with highest fat concentration (2.92\%) record at the second cropping season. 
Furthermore, at the first cropping season (2018), it was observed that the control plant gave highest values of protein $(22.10 \%)$ and fat contents $(22.10 \%)$ while at the second cropping season (2019) control plant also gave the highest moisture $(0.88 \%)$ and carbohydrate concentration $(21.79 \%)$ compared to other treatments.

Table 1. Comparative effects of different fertilizer types on proximate composition of Pumpkin (Cucurbita maxima L.).

\begin{tabular}{|c|c|c|c|c|c|c|c|c|c|}
\hline $\begin{array}{l}\text { Years of } \\
\text { Evaluation }\end{array}$ & $\begin{array}{l}\text { Fertilizer } \\
\text { Types }\end{array}$ & $\begin{array}{r}\text { Moisture } \\
\text { Content }(\%) \\
\end{array}$ & $\begin{array}{l}\text { Ash } \\
(\%)\end{array}$ & $\begin{array}{r}\text { Protein } \\
(\%) \\
\end{array}$ & $\begin{array}{r}\begin{array}{r}\text { Calcium } \\
(\mathrm{mg} / \mathrm{100} \mathrm{g})\end{array} \\
\end{array}$ & $\begin{array}{r}\text { Ascorbic acid } \\
(\mathrm{mg} / \mathrm{100} \mathrm{g}) \\
\end{array}$ & $\begin{array}{r}\text { Carbohydrate } \\
(\%) \\
\end{array}$ & Fat $(\%)$ & Fiber (\%) \\
\hline \multicolumn{10}{|l|}{2018} \\
\hline & Control & $0.86 \mathrm{ab}$ & $0.93 c$ & $22.10 \mathrm{a}$ & $1.00 \mathrm{~b}$ & $180.00 \mathrm{c}$ & $61.54 \mathrm{ab}$ & $22.10 \mathrm{a}$ & $0.94 \mathrm{~d}$ \\
\hline & FertiPlus & $0.83 b$ & $0.99 b$ & $19.35 d$ & $1.00 \mathrm{a}$ & $266.67 \mathrm{a}$ & $56.52 \mathrm{c}$ & $19.35 d$ & $2.80 \mathrm{a}$ \\
\hline & NPK & $0.88 \mathrm{a}$ & $2.75 \mathrm{a}$ & $21.31 b$ & $1.20 \mathrm{~b}$ & $211.76 \mathrm{bc}$ & $64.21 \mathrm{a}$ & $21.31 \mathrm{~b}$ & $1.76 b$ \\
\hline & Organomineral & $0.86 \mathrm{ab}$ & $0.93 b$ & $20.77 \mathrm{c}$ & $0.80 \mathrm{~b}$ & $242.30 \mathrm{~b}$ & $52.18 \mathrm{~d}$ & $20.77 \mathrm{c}$ & $0.94 \mathrm{c}$ \\
\hline \multicolumn{10}{|l|}{2019} \\
\hline & Control & $0.88 \mathrm{a}$ & $0.92 \mathrm{c}$ & $1.16 \mathrm{c}$ & $61.29 b$ & $13.62 \mathrm{c}$ & $21.79 \mathrm{a}$ & $0.98 \mathrm{c}$ & $149.67 \mathrm{~d}$ \\
\hline & Fertiplus & $0.87 \mathrm{a}$ & $0.99 b$ & $0.95 d$ & $56.11 \mathrm{~d}$ & $19.34 \mathrm{a}$ & $19.40 \mathrm{c}$ & $2.92 \mathrm{a}$ & $230.01 \mathrm{~b}$ \\
\hline & NPK & $0.87 \mathrm{a}$ & $2.72 \mathrm{a}$ & $1.20 \mathrm{~b}$ & $61.66 \mathrm{a}$ & $9.06 \mathrm{~d}$ & $21.47 \mathrm{a}$ & $1.81 \mathrm{~b}$ & $222.35 c$ \\
\hline & Organomineral & $0.87 \mathrm{a}$ & $0.93 \mathrm{c}$ & $1.18 \mathrm{a}$ & $57.94 \mathrm{c}$ & $16.17 \mathrm{~b}$ & $20.59 \mathrm{~b}$ & $0.99 \mathrm{c}$ & $251.60 \mathrm{a}$ \\
\hline
\end{tabular}

Note: Means within columns with the same letter(s) are not significantly different by DMRT at $\mathrm{P}=0.05$.

Table 2. Comparative effects of different fertilizer types on pigments concentration of Pumpkin (Cucurbita maxima L.).

\begin{tabular}{llrr}
\hline $\begin{array}{l}\text { Years of } \\
\text { Evaluation }\end{array}$ & Fertilizer Types & Chlorophyll & Carotenoid \\
\hline 2018 & & & \\
& Control & $0.63 \mathrm{~b}$ & $9.65 \mathrm{~b}$ \\
& FertiPlus & $0.75 \mathrm{a}$ & $10.32 \mathrm{a}$ \\
& NPK & $0.54 \mathrm{c}$ & $10.55 \mathrm{a}$ \\
& Organomineral & $0.62 \mathrm{~b}$ & $10.33 \mathrm{a}$ \\
& & & \\
& Control & $0.65 \mathrm{c}$ & $8.40 \mathrm{~d}$ \\
& Fertiplus & $0.77 \mathrm{a}$ & $9.65 \mathrm{~b}$ \\
& NPK & $0.56 \mathrm{~d}$ & $10.01 \mathrm{a}$ \\
& Organomineral & $0.74 \mathrm{~b}$ & $9.48 \mathrm{c}$ \\
\hline
\end{tabular}

Note: Means within columns with the same letter(s) are not significantly different by DMRT at $\mathrm{P}=0.05$.

\section{DISCUSSION}

The Fertilizer types significantly influence most of the proximate concentrations of pumpkin, the highest carotenoid concentration recorded in the pumpkin treated with fertilizers might be as a result of nutrients released by fertilizer, which enhances proximate and pigments concentration in crop (Akanbi et al., 2010; Olaniyi et al., 2010). This results was in conformity by other research which reported high carotenoid values in pumpkin grown with nitrogen based fertilizer or organic fertilization (Biesiada et al., 2009)

It was observed that, NPK has more influences on the proximate and pigments concentration of pumpkin than other fertilizer. This result was in agreement with the previous findings of Olaniyi \& Akanbi (2007), who reported the application of fertilizer in improvement of proximate concentration of fluted pumpkin.

More so, at the second cropping season (2019) control plant also gave the highest carbohydrate, this results corroborates with Adekayode (2004). The high moisture content in control plants is in agreement with the findings of Adetuyi et al. (2011), also in accordance with the finding of Gopalan et al. (2007) who reported high moisture content in vegetable.

\section{ACKNOWLEDGEMENTS}

We the authors wish to appreciate the management of Federal University of Technology for providing the Laboratory apparatus for this research and we sincerely appreciate Professor R. D. Aladesanwa for support and contribution to this research, may God richly bless and reward you Sir.

\section{REFERENCES}

Adekayode F.O. (2004). The use of manure to increase the yield and quality of Amaranthus to feed rabbit in a humid tropical region. Journal of Animal and Veterinary Advances, 3(11): 758-762.

Aderi O.S., Udofia A.C. \& Ndaeyo N.U. (2011). Influence of chicken manure rates and inorganic fertilizer formulations on some quantitative parameters of fluted pumpkin (Telfairia occidentalis hook f.). Nigerian Journal of Agriculture, Food and 
Environment, 7(1): 9-15.

Adetuyi F.O., Osagie A.U. \& Adekunle A.T. (2011). Nutrient, antinutrient, mineral and bioavailability of okra Abelmoschus esculentus (L) Moench. American Journal of Food and Nutrition, 1: 49-54.

Akanbi W.B., Togun A.O., Adediran J.A. \& Ilupeju E.A.O. (2010). Growth, dry matter and fruit yield components of okra under organic and inorganic sources of nutrients. American Eurasian Journal of Sustainable Agriculture, 4(1): 1-13.

Akanbi W.B., Akande M.O. \& Adediran J.A. (2005). Suitability of composted maize straw and mineral nitrogen fertilizer for tomato production. Journal of Vegetable Science, 11(1): 57-65.

Akanbi W.B. \& Olaniyi J.O. (2007).Effect of organomineral and inorganic fertilizers on the yield quality of fluted pumpkin (Telfaria occidentalis hook F.). African Journal of Crop Science, 8: 347-350.

Aletor O., Oshodi A.A. \& Ipinmoroti K. (2002). Chemical composition of common leafy vegetables and functional properties of their leaf protein concentrates. Food Chemistry, 78: 63-68.

AOAC (1990) Official Methods of Analysis. Association of Official Analytical Chemists (AOAC), Washington, DC, USA.

Biesiada A., Nawirska A., Kucharska A. \& Sokôl-Lçtowska A. (2009). The Effect of Nitrogen Fertilization Methods on Yield and Chemical activity of pumpkin (Cucurbita moschata). International Food Research Journal, 16: 45-51.

Gopalan C., Sastri S.B.V. \& Balasubramanian S. (2007). Nutritive value of Indian foods. National Institute of Nutrition (NIN), ICMR, India.

Jariene E., Danilcenko H., Kulaitiene J., Gajewski M. \& Venskutoniene E. (2007). Quality of oil bearing pumpkin cultivars depending on the fertilization method. In: Nowaczyk P. (Ed.) Spontaneous and Induced Variation for the Genetic Improvement of Horticultural Crops. University of Technology and Life Sciences, Bydgoszcz, Germany, pp. 189-196.

Nicoli M.C., Anese M. \& Parpinel M. (1999). Influence of processing on the antioxidant properties of fruit and vegetables. Trends in food Science and Technology, 10: 94-100.

Nwite J.C., Igwe C.A. \& Obalum S.E. (2011). The contributions of different ash sources to the improvement inproperties of a Degraded ultisol and maize production in Southeastern Nigeria. America-Eurasian Journal of Sustainable Agriculture, 5(1): $34-$ 41.

Olaniyi J.O. \& Akanbi W.B. (2007).Effect of organo mineral and inorganic fertilizers on the yield quality of fluted pumpkin (Telfairia occidentalis hook F.). African Crop Science Conference Proceedings, 8: 347-350.

Olaniyi J.O., Akanbi W.B., Olaniran O.A. \& Ilupeju O.T. (2010). Effect of organic, inorganic and organominerals on growth, fruit yield and nutritional composition of okra (Abelmoscus esculentus). Journal of Animal and Plant Sciences, 9(1): 1135-1140.

Oloyede F.M., Obisesan I.O., Agbaje G.O. \& Obuotor E.M. (2012) Effect of NPK Fertilizer on Chemical Composition of Pumpkin (Cucurbita pepo Linn.) Seeds. The Scientific World Journal, Article ID 808196.

Omar N.F., Hassan S.A., Yusoff U.K., Abdullah N.A., Wahab P.E. \& Sinniah U. (2012). Phenolics, flavonoids, antioxidant activity and cyanogenic glycosides of organic and mineral - base fertilized cassava tubers. Molecules, 17: 2378-2387.

Sabrina B., Reda D.M. \& Houria E.B. (2012) Induction of Antioxidant Enzyme System by a Nitrogen Fertilizer NPK in Wheat Triticum Durum. Advances in Environmental Biology 6: 85-88. 